\title{
Combining participatory games and backcasting to support collective scenario evaluation: an action research approach for sustainable agroforestry landscape management
}

\author{
Federico Andreotti ${ }^{1,2,3,4}$ - Erika N. Speelman ${ }^{1} \cdot$ Karel Van den Meersche $e^{4,8,9} \cdot$ Clementine Allinne $^{4,5,6,7}$
}

Received: 1 November 2019 / Accepted: 2 June 2020 / Published online: 16 June 2020

(c) The Author(s) 2020

\begin{abstract}
The combined and interacting effects of land-use change, resource extraction and climate change threaten the sustainability of millions of mainly smallholder farms in tropical agroforested landscapes. In many of these landscapes, coordinated action among stakeholders at landscape level would help to address challenges such as pests and diseases, price crises and climate change. However, methods to facilitate the co-production of sustainable landscape management in such complex multi-stakeholder systems are currently largely lacking. In this paper, we present a novel approach to explore pathways for the sustainability transition of agroforestry systems. By combining participatory forecasting and backcasting approaches, based on serious games and future vision development, we explore relevant agroforestry management strategies for reaching sustainable future coffee-based agroforestry landscapes. We focused our research on the challenges faced in the main coffee-producing area in Nicaragua. Here, we organized five participatory game sessions to explore farmer decision-making processes, farming strategies and to develop new networks and stimulate social learning among farmers. In the associated backcasting workshop, the most influential game session participants joined technicians, researchers and municipality officials to collectively envision sustainable future landscape management. In all game sessions, farmers developed diversified coffee-based agroforested landscapes characterised by increased density and diversity of shade trees, for the purpose of income diversification as well as forest conservation. During the backcasting workshop, the participants identified policy instruments and community-based solutions for the transition to sustainable landscapes. Our participatory approach facilitated discussion on landscape planning among farmers and other stakeholders and allowed the outline of a pathway towards the collective envisioned future landscape. The combination of participatory forecasting and backcasting proved to be a helpful tool to support multi-stakeholder processes towards sustainable landscape management in this and other complex landscapes.
\end{abstract}

Keywords Sustainability transition $\cdot$ Transformative change $\cdot$ Forecasting $\cdot$ Role-playing game $\cdot$ Agroecology $\cdot$ Future studies

Handled by Tobias Plieninger, Georg-August-Universitat Gottingen, Germany.

Electronic supplementary material The online version of this article (https://doi.org/10.1007/s11625-020-00829-3) contains supplementary material, which is available to authorized users.

Federico Andreotti

federico.andreotti@wur.nl

Extended author information available on the last page of the article

\section{Introduction}

The concept of sustainability transition is increasingly used in research and beyond to refer to the process of transforming current agricultural and food systems towards sustainable alternatives (Meynard et al. 2017; Gaitán-Cremaschi et al. 2019). Sustainability transition envisions the development of new pathways shaping future, more sustainable agricultural and food systems (Altieri 1989; Duru et al. 2015; Van der Ploeg et al. 2019; Schiller et al. 2019). New transition pathways can couple technological innovations such as agronomic practices 
with non-technological innovations such as cooperation between actors (Bergez et al. 2014; Meynard et al. 2017; Gaitán-Cremaschi et al. 2019). Sustainability pathways are used to create alternative agricultural and food systems in which evaluating new perspectives from agricultural practices to landscape management are key (Duru et al. 2015; Schiller et al. 2019). Landscape approaches play a central role in such a sustainability transition (Nelson and Phillips 2018; Andrieu et al. 2019) by aiming to harmonize conservation and development goals through the joint management of livelihoods and the associated ecosystems (Sayer et al. 2013).

Sustainable agroforestry practices can support landscape management and enhance forest conservation, agrobiodiversity, food production and livelihoods (Herrero-Jáuregui et al. 2019). At the landscape level, tree diversity within the agroforestry systems (AFS) has an important ecological function as biological corridors and habitats and is essential to the conservation of forest-dependent biodiversity or agricultural production (van Noordwijk et al. 2016; Andreotti et al. 2018). AFS play a major role in the transformation of agriculture towards sustainable landscapes (Poole and Donovan 2014; Rapidel et al. 2015) and offers a wide range of environmental, social, and economic benefits at farm as well as landscape level. However, ways to capitalize on this potential at landscape level have not yet been fully explored (Kabaya et al. 2019; Newell 2019).

The most studied AFS connecting management practices and landscape approaches are coffee-based AFS (Tscharntke et al. 2011; Cerda et al. 2017) and cacao-based AFS (Saj et al. 2017; Andreotti et al. 2018). Coffee production in the tropics has traditionally been done in AFS with coffee being a shade-tolerant species and the shade trees serving to maintain soil fertility and to create a beneficial microclimate (Sauvadet et al. 2019). However, in more recent decennia, the general trend has been towards shade reduction and intensification of coffee management, leading to biodiversity losses (Moguel and Toledo 1999; Philpott et al. 2009; Jha et al. 2014). While this is true for conventional AFS, organic AFS continues to have higher shade levels and more tree strata than conventional AFS (Haggar et al. 2012), as well as more tree species richness across the landscape (Haggar et al. 2015).

Rethinking and developing management strategies agroecosystems towards more sustainable agroforested landscapes have been addressed through serious games (García-Barrios et al. 2008; 2015; Garcia et al., 2018) and action research based on local knowledge and beliefs (Bergez et al. 2014; Kishita et al. 2016). Action research allows to study and rethink the farming system as a biophysical, economic and social subject shaping scientific and local knowledge and practices (Warner 2007; Hoolohan et al. 2018). In addition, action research has been used extensively to redesign sustainable farming systems (Altieri 1989; Mendez 2008; Tejedor and Segalas 2018).

A well-developed inclusive action research approach to learn about, discuss and explore the complexity of the many dimensions of contested landscapes is participatory gaming (Speelman et al. 2017; Moreau et al. 2019). The gaming approach has been increasingly used in research and development. One of the most successful examples of a gaming approach is the companion modelling approach (ComMod), which aims to facilitate collective learning about complex social-ecological system among diverse actors (Étienne 2013). By playing a game that mimics part of the real system, stakeholders explore the potential impacts of their actions, while sharing their knowledge and understanding of the functioning of the system at hand.

Most of the gaming literature aims at better understanding social-ecological systems dynamics under specific conditions and exploring what-if scenarios often in a participatory setting with stakeholders (Barnaud et al. 2010; Moreau et al. 2019). As such, these participatory gaming methods fit within the so-called forecasting approaches in which scenarios of the future are evaluated (Vergragt and Quist 2011; Hazard et al. 2018). While games taking a forecasting approach have, for example, shown to help coordinate farmers' land-use decisions at the landscape level discussing their socio-economic benefits (Speelman et al. 2014a; Hazard et al. 2018), forecasting role-playing games can also limit the player's imagination for different perspectives from the ones presented in the games (Villamor and van Noordwijk 2011). In contrast to the forecasting approach in which future systems are explored from the current system state and under current system conditions, backcasting is an approach that focuses on what should happen in the future rather than what could happen (Vergragt and Quist 2011; Kok et al. 2011; Duru et al. 2015). Backcasting as an approach allows participants to define a desirable future from which the steps required to reach this future vision will be identified in a backwards order as so-called opportunities, and potential events that will challenge reaching the vision, which are the so-called obstacles (Kok et al. 2011; Davies 2014; Duru et al. 2015; Kishita et al. 2016).

In this paper, we present a novel approach aiming to support collective scenario evaluation towards a landscape sustainability transition. To achieve this objective, we applied an action research approach based on participatory forecasting through serious gaming and participatory backcasting workshops. We demonstrate the method by applying it to a case study of complex coffee agroforestry systems in Nicaragua, a biodiversity hotspot where around $80 \%$ of the land is cultivated (Somarriba et al. 2017) and a major challenge in land management is the conservation of biodiversity while simultaneously securing rural livelihoods (Harvey et al. 2008; Speelman et al. 2014b; Beveridge et al. 2019). 
Central America is also one of the regions most exposed to climate change (Imbach et al. 2017). Nicaragua is particularly vulnerable to climate change due to its geographic, social, economic and environmental conditions (MartínezValle et al. 2017). Coffee is its main produce (Imbach et al. 2017; Somarriba et al., 2017) and coffee farmers face the direct and indirect impacts of climate change and land conversion (Downing et al. 1999) with predictions of substantial decreases in the total area suitable for coffee production (Laderach et al. 2011). Increasing the sustainability of coffee-based agroforestry systems in Nicaragua is key to sustaining local livelihoods (Harvey et al. 2014; Goodall et al. 2015; Somarriba et al. 2017).

\section{Methods}

\section{Study area}

The municipality Tuma-La Dalia $\left(13^{\circ} 08^{\prime} \mathrm{N} 85^{\circ} 44^{\prime} \mathrm{W}\right)$ is situated on the border of the Matagalpa and the Jinotega departments in central Nicaragua where steep and mountainous terrain predominate (Fig. 1). The area is located at an altitude ranging from $400 \mathrm{~m}$ to $850 \mathrm{~m}$ (Cerda et al. 2017, 2019). The climate in Tuma-La Dalia is subtropical with temperatures ranging between 22 and $24{ }^{\circ} \mathrm{C}$ (respectively, the daily mean temperature in the cold and in the hot months) with a distinct rainy season from May to November and an annual rainfall average of $2200 \mathrm{~mm}$ (Montagnini 2017; Cerda et al. 2019; Sepúlveda et al. 2020). The local landscape is fragmented with around $60 \%$ of the land characterised as low natural forest cover (Somarriba et al. 2017). Land use consists of pastures for cattle ranching, field crops for the production of staple cereals like rice, maize and beans, home gardens and coffee-based AFS (Somarriba et al. 2017). Household income depends exclusively on these activities, and is very low with an annual average cash flow of around $134 \mathrm{USD} \mathrm{ha}^{-1} \mathrm{year}^{-1}$ (Somarriba et al. 2017). This is in particular due to the impact of fungi (coffee rust), pests (affecting staple cereals), and the alternation of drought and excessive rainfall (Sepúlveda et al. 2018). Tuma-La Dalia is the main town within the municipality and is surrounded by several remote smallholder communities. The research presented in this paper was associated to a project entitled "System approach for the transition to biodiversified agrosystems (STRADIV)" which ran from 2015

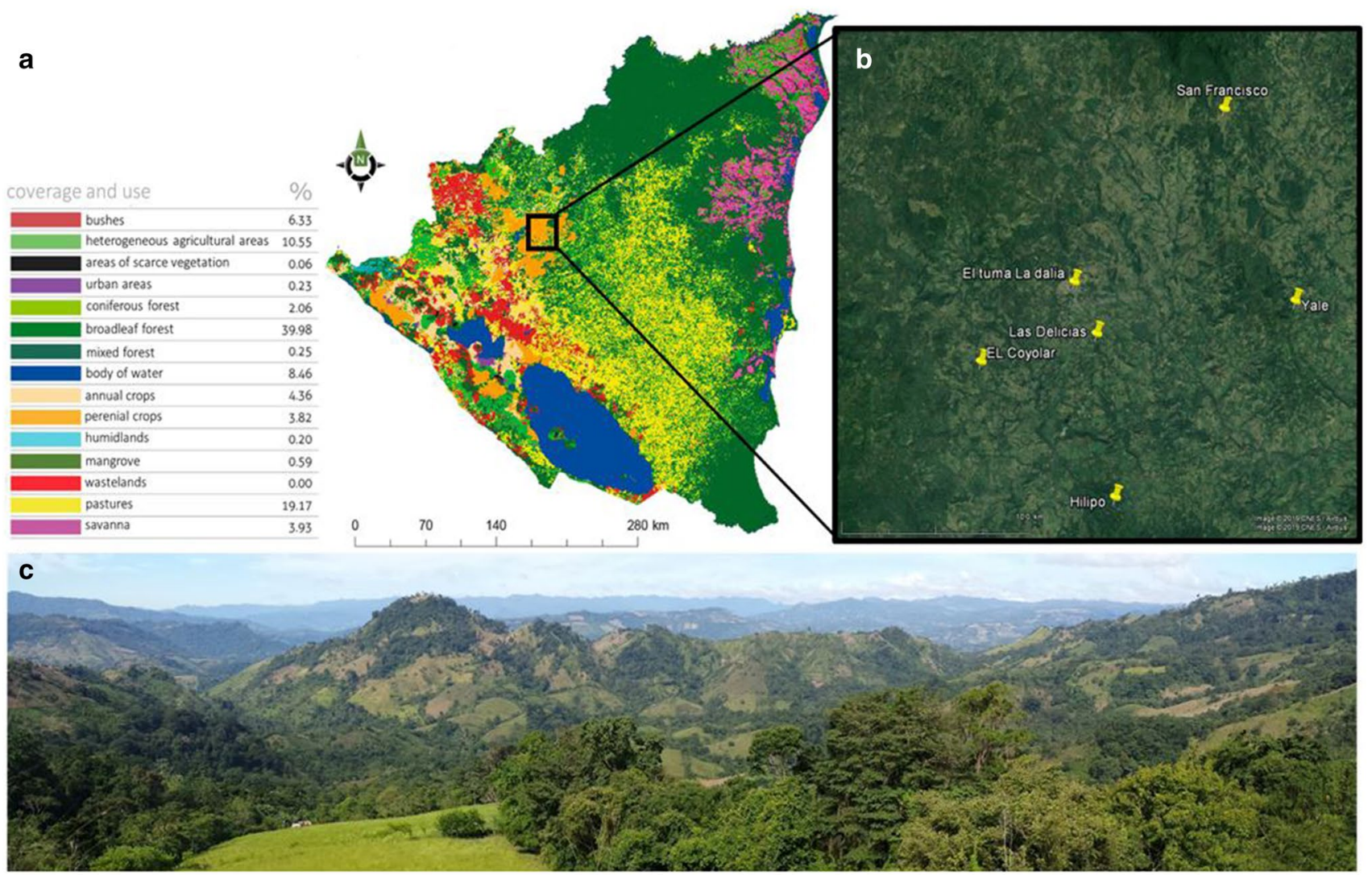

Fig. 1 Map of Nicaragua land uses (adapted from Hernández Sandoval et al. 2011): a location of the five studied communities around Tuma-La Dalia in the coffee area of Matagalpa department (b) and view of the landscape observed from the community of Yale (c) 
to 2018. The project aimed to develop a new methodological framework for the co-design and assessment of innovative biodiversified cropping systems (the authors are available for more information about the project). The research was executed in five of the communities surrounding Tuma-La Dalia, namely: Las Delicias, Yale, El Coyolar 2, Hilipo 2, San Francisco (Fig. 1). These five communities are located at an altitude ranging between 600 and $800 \mathrm{~m}$ (Las Delicias, El Coyolar 2, Hilipo 2 and Yale 600-700 m; while San Francisco 700-800 m).

\section{Combining participatory forecasting games with backcasting workshops}

The combination of forecasting game sessions with a backcasting workshop allowed us to develop a novel approach for envisioning sustainability transition pathways as well as to co-produce and evaluate future landscapes (Fig. 2). The role of the participants in landscape planning was explored in the games and then build upon to make a path for the future during the backcasting workshop.

Through the game sessions, we were able to collect data on the current landscape scenario and on the communication and leadership of the participants. Thanks to this starting point we built up a backcasting workshop in which we invited different relevant stakeholders and the leaders from the communities selected during the game sessions. During the backcasting workshop, the participants envisioned their desired future landscape starting from the current landscape scenario. Then, from the future vision the participants went backwards defining opportunities and obstacles needed to reach their ideal scenario. In "Game sessions and data analysis" we encompass the detailed steps of the game sessions and in the "Backcasting workshop" the steps of the backcasting workshop.

\section{Game sessions and data analysis}

As a forecasting gaming method, the RESORTES board game (Speelman and García-Barrios 2010) was used. The RESORTES game facilitates agricultural and agroforestry land-use planning discussions including among stakeholders (Speelman et al. 2014a). The game revolves around individual land-use decisions and includes options for collaboration among players at the landscape level of the game. Players receive rewards based on the combination of their individual and their collective decisions. The game board represents a mountainous landscape with native forests and possibilities for agroforestry and is divided into four quadrants of nine hexagon plots each (Fig. 3). The game is played by six players who manage four hexagon fields each. The remaining hexagons represent a virgin forest. In the first four rounds, players allocate their fields on the board-one field per player per round. The selected location of the fields remains unchanged throughout the game. In subsequent rounds, players select the type of land-use for each of their fields without taking turns. The game has four land-use options, of which two distinct options represent low-risk land-use types while another two distinct options represent high-risk land-use types. Players collectively decide when they are

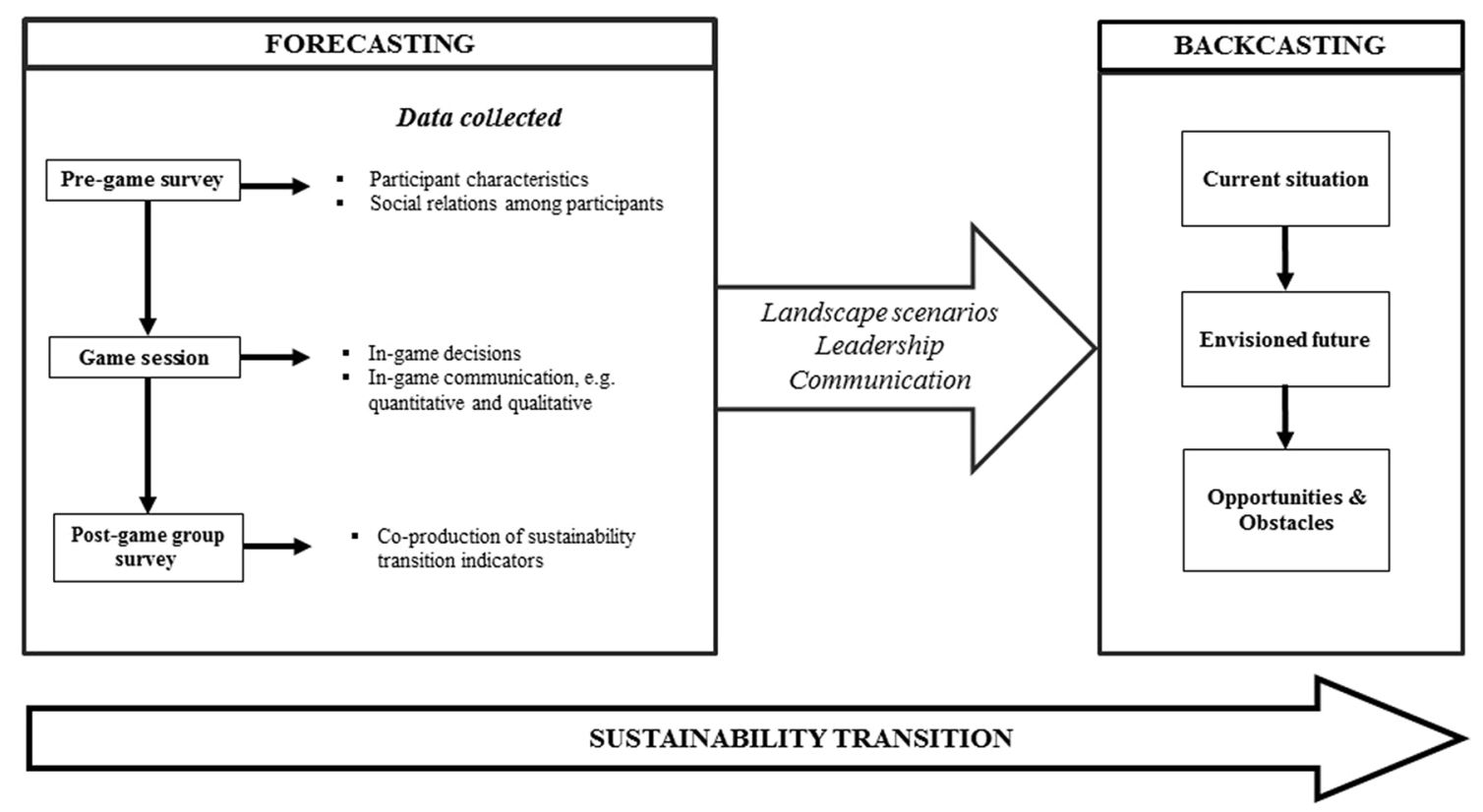

Fig. 2 Sustainability transition pathways combining forecasting game sessions with backcasting workshop for co-producing desirable future landscape 


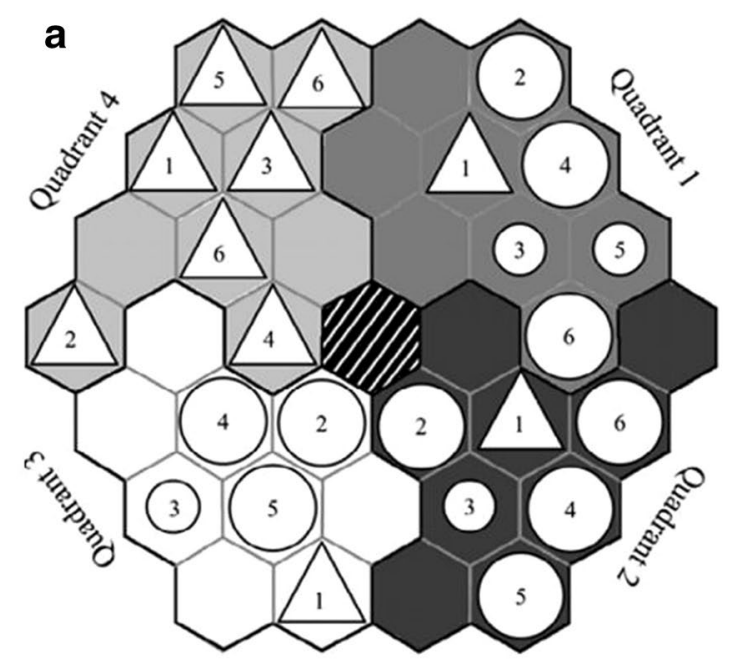

Fig. 3 Schematic representation of the RESORTES game board with the field locations in four quadrants in distinct colours and the settlement in the centre of the board (striped). Two contrasting examples of participant's field and land-use allocations; a best possible coordina-

ready to end the round. At the end of each land-use selection round, players receive points based on the land-use types selected for their plots and the benefits of their participation (if any) on one or both of the collaboration schemes. Points per land-use types were determined at the end of each round by throwing two dice that reflect the range of high-risk prices and low-risk prices. The two collaboration schemes for landscape planning that could lead to additional points reflected economic benefits from successful collaboration.

To better match the agroforested landscape in Nicaragua, we adapted the original RESORTES game (for a detailed description of the RESORTES game, please see Speelman et al. 2014a, and Supplementary Annex 1) in three aspects to better fit the local context of coffee-based agroforestry in Nicaragua: (1) the four land-use options, (2) changing economic situations, and (3) the collaboration schemes. The adaptation of the game was developed using the expertise of the authors and by testing it with local technicians. In this RESORTES adaptation the land-use types were inspired by Moguel and Toledo (1999): (a) monoculture full sun coffee, (b) commercial polyculture coffee-based agroforestry system, (c) highly diversified traditional coffee-based agroforestry system, and (d) highly diversified traditional organic coffee-based agroforestry system (Fig. 4). Land-use types $\mathrm{a}$ and $\mathrm{b}$ were both regarded as having a higher risk than options $\mathrm{c}$ and d. Risk was defined as income losses in case of coffee failure due to climate change or pest and diseases (Lasco et al. 2014). Several studies pointed out that this risk is higher in full sun coffee systems compared to more diversified system (Schroth et al. 2000; Avelino et al. 2012; Montagnini 2017). In addition to that, increasing tree diversity allows farmers to have more products such as timber,

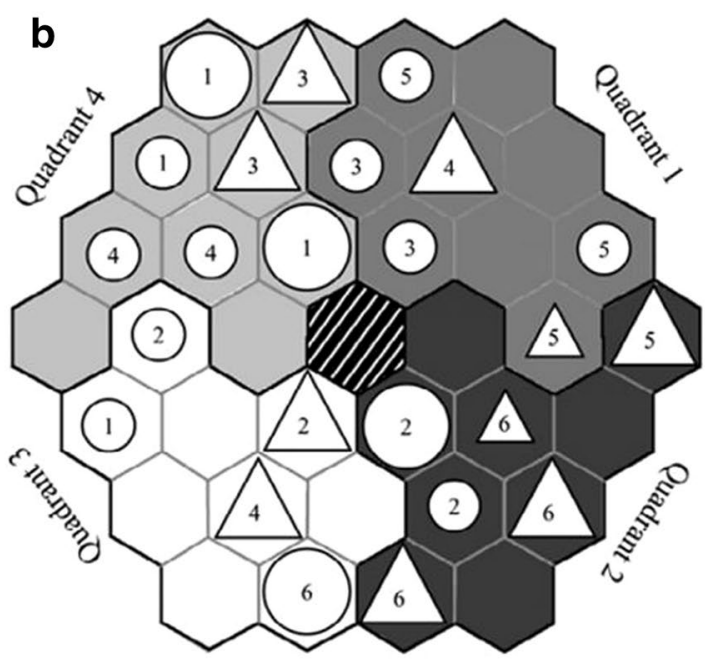

tion leading to maximum additional points for one individual player as well as board-wide, and $\mathbf{b}$ little coordination leading to no additional points (Source: Speelman et al. 2014a)

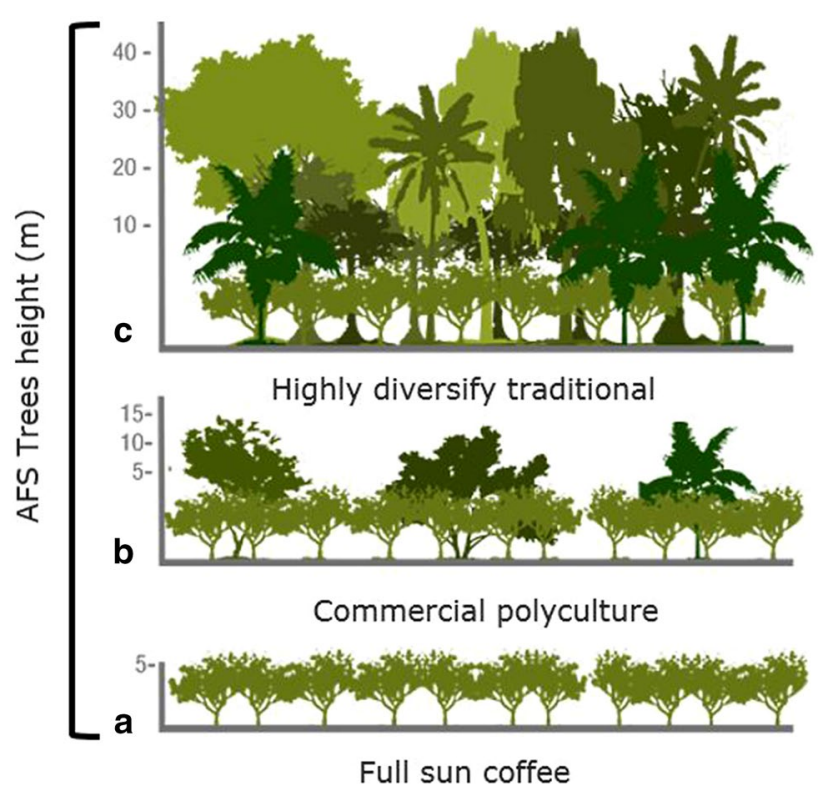

Fig. 4 Land-use types used in the game sessions representing the coffee-based AFS in Nicaragua defined as: a monoculture full sun coffee, $\mathbf{b}$ commercial polyculture coffee-based agroforestry system, $\mathbf{c}$ highly diversified traditional (or option d organic) coffee-based agroforestry system (Adapted from Moguel and Toledo 1999)

fodder, and fruits that can potentially create a buffer against income losses derived from pure coffee production (Lasco et al. 2014; Martínez-Valle et al. 2017; Schiller et al. 2019).

Three distinct economic situations were defined to be explored in the game and these included: (1) a substantially higher price for organic coffee, (2) prices being equal for conventional and organic coffee, (3) the price of chemical 
fertilizer being substantially lower than usual. The two collaboration schemes were based on economic benefits from successful collaboration through realistic options within the Nicaraguan landscape: forming an organic cooperative and participating in ecotourism. To meet the requirements for obtaining additional points through the cooperative scheme, eight out of the nine fields within a quadrant needed to have an organic and highly diversified traditional coffee-based AFS. If the requirements were met, all players who owned a field in the respective quadrant received five additional points per round. The ecotourism scheme requires eight fields per quadrant to be covered with highly diverse traditional conventional and/or organic coffee-based AFS and rewards all who hold a field in the respective quadrant five additional points per round. Players collectively decide how many land-use allocation rounds they play.

We employed the elaborate data collection and analysis scheme developed by Garcia-Barrios in Speelman et al. (2014a). The monitoring and analysing scheme consisted of: pre-game surveys, in-game decision registration scheme, quantitative and qualitative communication analysis during and after the game through video observation, and postgame group survey in the debriefing of the game. In the pre-game survey, we used a structure questionnaire to collect information on the participant characteristics such as age, place and farming strategy, assess the social relations and level of acquaintance among participants (self-reported relatedness). Following Speelman et al. (2014a), we performed a qualitative and quantitative analysis of the game sessions assessing: (1) individual verbal communication input, (2) leadership, both assessed as perceived. Through a post-game group survey and a general debriefing of the game each player discussed: (1) his/her role during the game of the players in terms of successful collaboration, (2) his/ her choices made between the different options for land-use with a focus on organic and conventional agriculture. Later on during the post-game group survey five indicators for the sustainability transition of the landscape were chosen. The authors then compared the same indicators with their optimal values obtained by literature review. This evaluation was made to compare the reality of the communities studied with other communities in the same study area with similar coffee-based AFS landscapes.

All game sessions workshop took place between July and August 2017 in the different communities around the town of Tuma-la Dalia namely, Las Delicias (group 1), Yale (group 2), El Coyolar 2 (group 3), Hilipo 2 (group 4), San Francisco (group 5) (Fig. 1). In all game sessions, six local stakeholders participated in the game, five of which were farmers and one was a technician who worked as an extension officer on an NGO lead the participatory project in the communities. The game facilitator was familiar with the communities and knew some of the participants. Participants were invited using the snowballing method (Goodman 1961). In each community, the contact farmer familiar to the STRADIV project was asked to invite four additional farmers who owned a coffee-based AFS to participate in the game session. Game sessions were video-taped and voice recorded for analysis purposes with participants' consent.

\section{Backcasting workshop}

As a backcasting method, we adapted the participatory methodology to design agroecological transition and to support a multi-stakeholder arena presented by Duru et al. (2015). The backcasting exercise we developed aimed to support the discussion of social, economic and environmental aspects of sustainability transition at the landscape level. The exercise was divided into three steps in which the participants collectively developed their view on the: (1) the current situation, (2) their vision of the ideal situation in 2040, (3) the backwards steps (opportunities and obstacles) required to reach the ideal situation. During the presentation of the current situation, we showed in the workshop the five indicators co-produced with the participants during the post-game group survey and confirmed by literature review. Starting from the indicators of the current situation, the participants took part in a plenary discussion envisioning how these indicators could evolve in an imaginary and ideal situation in 2040. Once the consensus was reached on how the ideal future should be, they were asked them to identify backwards transition pathways to reach the ideal scenario. To do this, the participants wrote individually on different coloured cards the opportunities and the obstacles. Then, the collected cards were placed on a board for coproducing with the participants' clusters of similar opportunities and obstacles. Therefore, once the clusters were made, we presented the results to the participants asking them for additional feedback or consensus. After all the participants agreed with the co-produced backwards transition pathway we invited the participants to a debriefing session.

Our one-day backcasting workshop was organised following the five-game sessions at the end of August 2017. The participants were five community leaders as identified from the game sessions (one of each game session), three technicians who also participated to the game sessions, three researchers specialized in coffee-based AFS and two members of the municipality of Tuma-La Dalia who were involved in a development project on micro-credit and farm products diversification. The workshop was conducted by two facilitators. During the backcasting session, data were collected by collective writing and voice recording with the consent of the participants.

Our study did not require an ethical approval considering the low risks involved in the process and since the familiarity that the farmers have with the STRADIV project. In 
fact, participants knew beforehand what was going to happen during the game sessions and the backcasting workshop. In addition, they were aware that they were free to participate or to leave the activities when they wanted, and they knew that the data collected were anonymised.

\section{Results}

\section{Game outcomes: pre-game survey, game sessions and post-game survey}

The pre-game survey allowed us to define the characteristics of participants per community (Table 1). Group 1 has the lowest farm total land (2.4 ha) and the lowest coffee-based AFS (1.2 ha), while group 2 had the highest farm total land (10.7 ha) and coffee-based AFS (6.1 ha). These two groups represent also the range of the five communities concerning the coffee selling price which is $530 \$ \mathrm{t}^{-1}$ for group 1 and $700 \$ \mathrm{t}^{-1}$ for group 2 . Both group 1 and 2 also have no variation in coffee price as they belonged to two different small cooperatives that buy coffee at a fixed price. In the case of group 1 the price they sell it is at a minimum price, while in case of group 2 it is a premium price justified by the high quality of the product and reliability of the producer. Group 1 had on average the youngest participants (average age of 35 years), while the oldest group was group 3 (average age of 54 years). Group 3 has the highest relatedness index (83\%).

During the game sessions, most players allocated their fields in two of the board's four quadrants (QO in Table 2). This choice was justified by reproducing their own farm, which most of the time is sparing and in non-consecutive forest area. On average, only one player per game session decided to allocate the four fields into four different quadrants.

The five-game sessions resulted in different outcomes in terms of landscape configurations (Table 2). In all rounds, the percentage of selected of coffee-based land-use was between 0 and 100. The lowest average per round was 0 and the highest was 87.5. In group 1, three players (players 1, 3, 4) always selected more than $50 \%$ of highly diversified traditional organic coffee-based AFS (option d). In group 2 the average per game session was $39.6 \%$ for highly diversified traditional coffee-based AFS (option c) and $42.7 \%$ highly diversified traditional organic coffee-based AFS (option d). In group 3 not a single-player decided to use commercial polyculture coffee-based AFS (option b). In this group, two players decided to play always with the same option: highly diversified traditional coffee-based AFS (option c, player 6) and highly diversified traditional organic coffee-based AFS (option d, player 5). Only in group 4, all the players used the four land-use options available at least once during the four rounds. In this group, the average per game session for commercial polyculture coffee-based AFS (option b) was the highest (30.2\%) compared to the other groups. At the same time in group 4 the highest average per game session was highly diversified traditional organic coffee-based AFS (option d) with 33.3\%. In group 5, four players (players 1, $3,4,5,6)$ selected at least for two rounds $100 \%$ of highly diversified traditional coffee-based AFS (option c). In all groups the land-use option of monoculture full sun coffee (option a) was infrequently utilized: the highest average per game session was in group 4 with $20.8 \%$ and the lowest in three groups (groups 1,3,5) with $8.3 \%$.

Round by round, players adjusted the land use of their fields. Most players changed the initial allocation by increasing the diversity of the land-use on the four plots (Table 2). In group 3 and 4, a total of three players switched their land use from an initial organic to a conventional one. While in groups 1, 2, 3 and 5, seven players switched their land use from conventional to organic. The rest of the players, who represent the majority of the players, kept their land use during the game rounds. In group 1 the total average percentage of selected coffee-based organic AFS land-use types was $72.9 \% ; 42.7 \%$ in group $2 ; 32.3 \%$ in group $3 ; 31.3 \%$ in group 4 and $22.9 \%$ in group 5 .

The additional points gained by the groups of players showed diverse levels of cooperation (Table 3 ). In group 1 the total additional points gained by all the players during the game sessions was 180 additional points; 155 additional points in group 2; 295 additional points in group 3; 75 additional points in group 4 and 230 additional points in group 5 .

While all players commented during the game sessions, the individual differences in quantified communication were considerable between players, ranging from 3 to $25 \mathrm{com}$ ments per player (Table 1). Only in group 3, a single-player made $70 \%$ (26 comments) of the total number of comments. Group 3 also had the highest average comments made per player during the game (14 comments) (Table 1).

In most of the groups, the number of comments followed the same trend of the perceived leadership (Fig. 5). In groups 2, 3 and 5 the players that made the most comments were also the ones with the highest perceived leadership (respectively players 3,5 and 3 ). While in groups 1 and 4 even though one player per group made most of the comments (in both cases player 1) they were not perceived by the other players as leaders. In fact, they identified two different players as the leaders (respectively, players 4 and 2).

During the debriefing group discussion after the game sessions five indicators were identified to describe the current situation and desired future during the backcasting workshop covering the complexity of sustainability transition encompassing socio-economic and ecological aspects, namely: (1) Productivity: the coffee yield; (2) Soil fertility: soil organic matter content (\%); (3) Biodiversity: coffee 
Table 1 Pre-survey games participants' characteristics from the five-game sessions played in the five communities (groups): age (\#), land holdings (ha), relatedness index $(\%)$, coffee production $\left(\mathrm{t} \mathrm{ha}^{-1}\right)$, coffee selling price $\left(\$ \mathrm{t}^{-1}\right)$ the average comments made per player during the game (\#)
Farmers communities characteristics

\begin{tabular}{|c|c|c|c|c|}
\hline Age (years) & Group & Mean & St.dev. & Range \\
\hline & 1 & 35 & \pm 13.85 & $18-59$ \\
\hline & 2 & 41 & \pm 9.98 & $28-53$ \\
\hline & 3 & 54 & \pm 16.26 & $20-66$ \\
\hline & 4 & 40 & \pm 16.68 & $18-62$ \\
\hline & 5 & 39 & \pm 4.71 & $30-44$ \\
\hline \multirow[t]{5}{*}{ Farm total land (ha) } & 1 & 2.4 & \pm 1.99 & $0.7-6.3$ \\
\hline & 2 & 10.7 & \pm 7.65 & $1.4-23.1$ \\
\hline & 3 & 3.9 & \pm 1.02 & $2.8-5.7$ \\
\hline & 4 & 4.1 & \pm 2.01 & $0.4-6.7$ \\
\hline & 5 & 2.5 & \pm 0.32 & $2.1-2.8$ \\
\hline \multirow[t]{5}{*}{$\overline{\text { Coffee AFS (ha) }}$} & 1 & 1.2 & \pm 0.70 & $0.9-2.8$ \\
\hline & 2 & 6.1 & \pm 2.96 & $1.7-10.5$ \\
\hline & 3 & 2.3 & \pm 1.33 & $0.7-4.9$ \\
\hline & 4 & 2.4 & \pm 1.45 & $0.7-4.9$ \\
\hline & 5 & 2.5 & \pm 0.32 & $2.1-2.8$ \\
\hline \multirow{5}{*}{$\begin{array}{l}\text { Coffee Production } \\
(\mathrm{t} \text { ha-1) }\end{array}$} & 1 & 2.45 & \pm 0.76 & $2.1-4.2$ \\
\hline & 2 & 2.87 & \pm 0.87 & $2.8-5$ \\
\hline & 3 & 1.52 & \pm 2.18 & $0.7-5.6$ \\
\hline & 4 & 2.98 & \pm 0.27 & $2.8-3.4$ \\
\hline & 5 & 3.74 & \pm 0.96 & $2.1-4.9$ \\
\hline \multirow{5}{*}{$\begin{array}{l}\text { Coffee Selling Price } \\
(\$ \mathrm{t}-1)\end{array}$} & 1 & 514 & \pm 0.82 & $500-570$ \\
\hline & 2 & 700 & \pm 0.00 & 700 \\
\hline & 3 & 580 & \pm 50.99 & $500-650$ \\
\hline & 4 & 588 & \pm 26.08 & $530-600$ \\
\hline & 5 & 530 & \pm 0.00 & 530 \\
\hline \multirow[t]{5}{*}{ Relatedness index (\%) } & 1 & 70 & \pm 25.64 & $20-100$ \\
\hline & 2 & 73 & \pm 9.21 & $60-80$ \\
\hline & 3 & 83 & \pm 13.75 & $60-100$ \\
\hline & 4 & 80 & \pm 16.33 & $60-100$ \\
\hline & 5 & 60 & \pm 20.14 & $20-80$ \\
\hline \multirow[t]{5}{*}{ Comments (\#) } & 1 & 6 & \pm 5.28 & $1-15$ \\
\hline & 2 & 8 & \pm 4.20 & $3-16$ \\
\hline & 3 & 14 & \pm 8.03 & $4-26$ \\
\hline & 4 & 10 & \pm 4.24 & $3-16$ \\
\hline & 5 & 9 & \pm 2.67 & $5-12$ \\
\hline
\end{tabular}

The red color bars are designed to quickly display the different values 
associated trees species richness; (4) Market: selling price of the coffee (\$); (5) Land use: land expansion (ha). The five indicators collected during the post-survey were confirmed or adjusted bya literature review (Fraser et al. 2013; Wilson 2013; Poole and Donovan 2014; Martínez-Valle et al. 2017; Durand-Bessart et al. 2020).

In all groups, the most conflictual topic was between organic and conventional agriculture. Reasons for players adopting or not adopting organic management were collected during the game sessions (no. of comments). In the overall game sessions played in the five communities there were 11 comments in favour of organic agriculture pointing at: (1) higher selling price (3 comments); (2) sustainable management (6 comments) and ( 3 ) human health ( 2 comments). On the other hand, there were 17 comments made against organic agriculture pointing at: (1) lack of experience ( 5 comments); (2) labour intense ( 8 comments) and (3) low yield (4 comments).

\section{Backcasting workshop: developing sustainability transition pathways}

At the beginning of the workshop, participants worked on describing the current situation. Therefore, the five indicators identified during the post-game discussion in all game sessions were re-introduced (Fig. 6).

The productivity targets were discussed at length and only after $2 \mathrm{~h}$ discussion the participants reached consensus on the envisioned values for the indicators. Setting an ambitious productivity target for 2040 was the most important step for the participants. The discussion then moved onto organic coffee production and its currently low yields in relation to conventional coffee yields.

The participants agreed that the soil fertility targets were to be based on both the organic and conventional soil fertility values, as such the value was the average of both values.

The biodiversity targets were established by the participants starting from the current status of biodiversity in the coffee-based agroforestry systems.

The richness of the associated tree species in the agroforestry plots was evaluated in the post-survey game sessions in each of the sessions. After some discussions and sharing of knowledge and practices in particular about the management of biodiversity in their coffee-based AFS, the participants expressed interest and commitment to increase the plant diversity by continuing to share knowledge and practices of different trees species used in the communities.

Defining an envisioned market target highlighted how farmers receive different compensation when selling their coffee to local cooperatives or external companies. This difference in coffee prices in the current market system was pointed out as one of the key factors that needed to change to have a more equal and fair selling price for farmers. The participants proposed for the envisioned future a higher price for all organic and conventional producers. In addition to the envisioned improvements in the coffee production, participants discussed about diversifying the produce of these systems by initiating sales of associated fruits and seeds produced in the same agroforestry landscapes as a means to supplement and diversify local household income. The land use target showed that participants were not willing nor able to expand the AFS land. Discussions on this topic included the hard-working conditions, lack of time and lack of labour.

After completing and presenting the envisioned future situation and targets, the participants of the backcasting workshop made the necessary steps to reach that future by identifying potential opportunities and obstacles (Fig. 7). For each opportunity and obstacle identified, participants discussed possible policy instruments or community-based solutions that might drive towards sustainable transition. To achieve a higher coffee price, the participants proposed to form a larger cooperative that would include several communities and could provide a recognized label acknowledging their sustainable production practices and fair trade (Fig. 7). During the backcasting workshop, participants showed an interest to diversify their systems and produce. However, they showed little interest in further developing organic coffee production. They believed that organic production needs extensive labour requirements, considering also that more young people were leaving the countryside to find work in urban areas. As a consequence, farmers showed no interest in expanding their coffee-based AFS (Fig. 6) mainly due to limited labour availability. Farmers did envision the farming practices associated with their desired future to be based on reduced external inputs, in particular, chemical inputs, that would only be used when strictly necessary.

\section{Discussion}

This study contributes to the current toolbox of methods for participatory co-production of future landscapes by combining participatory forecasting and backcasting approaches for a sustainability transition in agroforestry management. The combination of forecasting games and an interactive backcasting workshop provided new insights on farmer decision-making in these systems. In addition, it offered a unique setting for local stakeholders, farmers and technicians, to share knowledge and experiences on the management of their coffee-based AFS. New relationships and networks were established to continue further discussions on agro-forestry management at farm as well as landscape level. Five game sessions were organized with six participants each, followed by one backcasting 


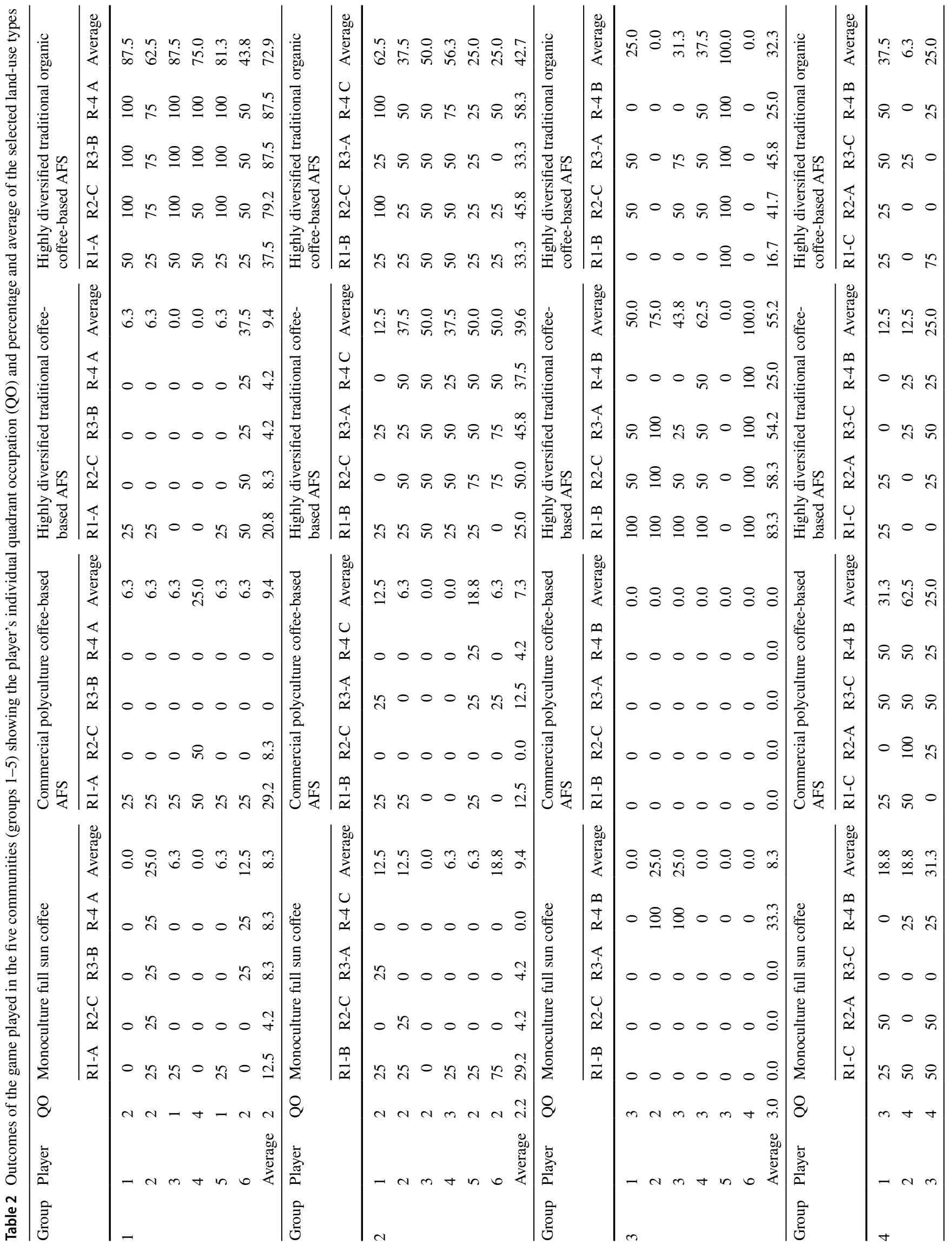




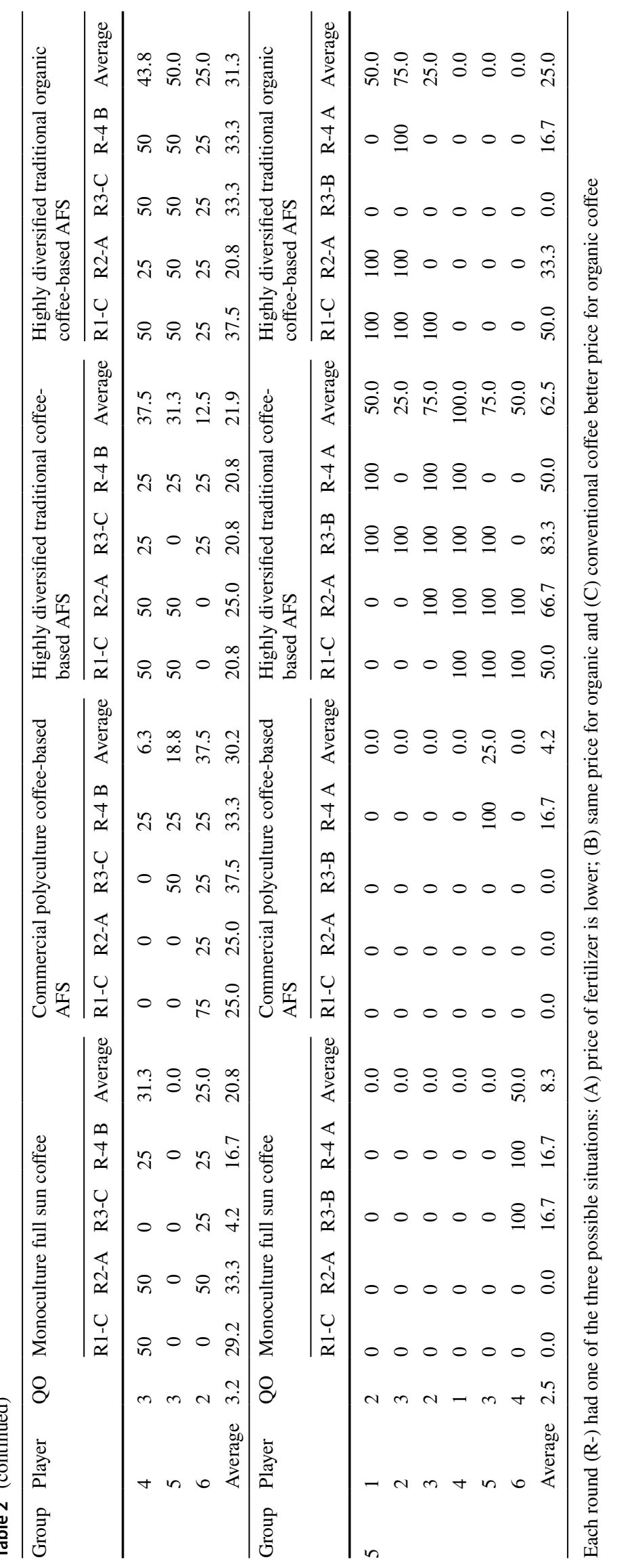


Table 3 Outcomes of the game played in the five communities (groups 1-5) showing the additional points obtained per player and total additional points per round per group

\begin{tabular}{|c|c|c|c|c|c|c|}
\hline \multicolumn{7}{|c|}{ Additional points } \\
\hline Group & Player & R1-A & $\mathrm{R} 2-\mathrm{C}$ & R3-B & R-4 A & Sum \\
\hline \multirow[t]{7}{*}{1} & 1 & 5 & 10 & 10 & 10 & 35 \\
\hline & 2 & 0 & 5 & 10 & 10 & 25 \\
\hline & 3 & 0 & 5 & 5 & 5 & 15 \\
\hline & 4 & 5 & 15 & 20 & 20 & 60 \\
\hline & 5 & 0 & 5 & 5 & 5 & 15 \\
\hline & 6 & 0 & 10 & 10 & 10 & 30 \\
\hline & Sum & 10 & 50 & 60 & 60 & 180 \\
\hline Group & Player & R1-B & $\mathrm{R} 2-\mathrm{C}$ & R3-A & R-4 C & Sum \\
\hline \multirow[t]{7}{*}{2} & 1 & 5 & 5 & 5 & 5 & 20 \\
\hline & 2 & 0 & 10 & 5 & 5 & 20 \\
\hline & 3 & 5 & 15 & 10 & 10 & 40 \\
\hline & 4 & 5 & 15 & 10 & 10 & 40 \\
\hline & 5 & 0 & 10 & 5 & 5 & 20 \\
\hline & 6 & 0 & 5 & 5 & 5 & 15 \\
\hline & Sum & 15 & 60 & 40 & 40 & 155 \\
\hline Group & Player & R1-B & $\mathrm{R} 2-\mathrm{C}$ & R3-A & R-4 B & Sum \\
\hline \multirow[t]{7}{*}{3} & 1 & 15 & 20 & 15 & 5 & 55 \\
\hline & 2 & 10 & 10 & 10 & 0 & 30 \\
\hline & 3 & 15 & 15 & 15 & 5 & 50 \\
\hline & 4 & 15 & 15 & 15 & 5 & 50 \\
\hline & 5 & 15 & 15 & 15 & 0 & 45 \\
\hline & 6 & 20 & 20 & 20 & 5 & 65 \\
\hline & Sum & 90 & 95 & 90 & 20 & 295 \\
\hline Group & Player & $\mathrm{R} 1-\mathrm{C}$ & $\mathrm{R} 2-\mathrm{A}$ & R3-C & R-4 B & Sum \\
\hline \multirow[t]{7}{*}{4} & 1 & 0 & 0 & 0 & 0 & 0 \\
\hline & 2 & 5 & 0 & 5 & 10 & 20 \\
\hline & 3 & 5 & 0 & 5 & 10 & 20 \\
\hline & 4 & 5 & 0 & 5 & 10 & 20 \\
\hline & 5 & 0 & 0 & 5 & 10 & 15 \\
\hline & 6 & 0 & 0 & 0 & 0 & 0 \\
\hline & Sum & 15 & 0 & 20 & 40 & 75 \\
\hline Group & Player & R1-C & R2-A & R3-B & R-4 A & Sum \\
\hline \multirow[t]{7}{*}{5} & 1 & 10 & 5 & 10 & 0 & 25 \\
\hline & 2 & 15 & 15 & 15 & 5 & 50 \\
\hline & 3 & 10 & 5 & 10 & 0 & 25 \\
\hline & 4 & 5 & 5 & 5 & 5 & 20 \\
\hline & 5 & 15 & 15 & 15 & 0 & 45 \\
\hline & 6 & 20 & 20 & 20 & 5 & 65 \\
\hline & Sum & 75 & 65 & 75 & 15 & 230 \\
\hline
\end{tabular}

Each round (R-) had one of the three possible situations: (A) price of fertilizer is lower; (B) same price for organic and (C) conventional coffee better price for organic coffee

workshop in which one participant of each game session participated to incorporate the outcomes and views of all participants from the various game sessions into the backcasting workshop. The workshop initiated discussion between farmers from different communities, technicians, 


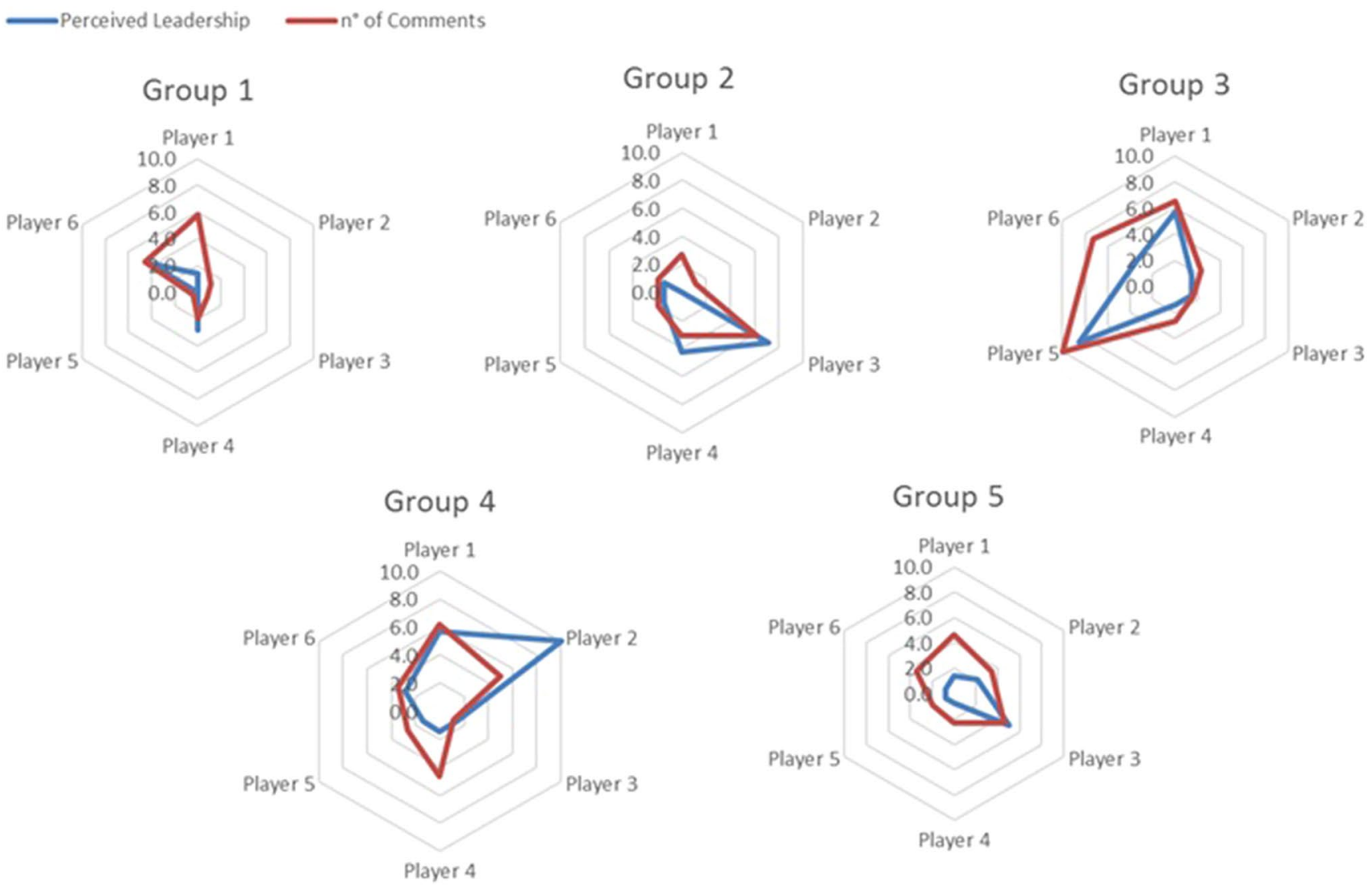

Fig. 5 Overview of the perceived leadership and number of comments made by the players during the game sessions of the five pilot game groups

researchers and the municipality, creating and/or reinforcing new networks and collaborations.

During five participatory forecasting gaming sessions, distinct agro-forested landscapes were developed with diverse combinations of the different coffee production types. Participants of the game sessions discussed at length about the different coffee production types and in particular organic vs non-organic systems when selecting their landuse types in the game landscape. This activity allowed and stimulated participants to share and discuss their knowledge, experiences and preferences related to coffee-based agroforestry landscapes. The composition of participants in each of the sessions created new interactions within the safe environment of the game. Communication and leadership showed to be important pillars for collaboration among participants, both were positively related to successful collaboration among players. Through this forecasting exercise, participants jointly explored the impacts of different land use management options on income, landscape composition and collaboration. Farmers shared their interest in developing a fairer market for all coffee producers: organic and conventional. During the backcasting exercise, they built on these lessons by envisioning a desired future and identifying

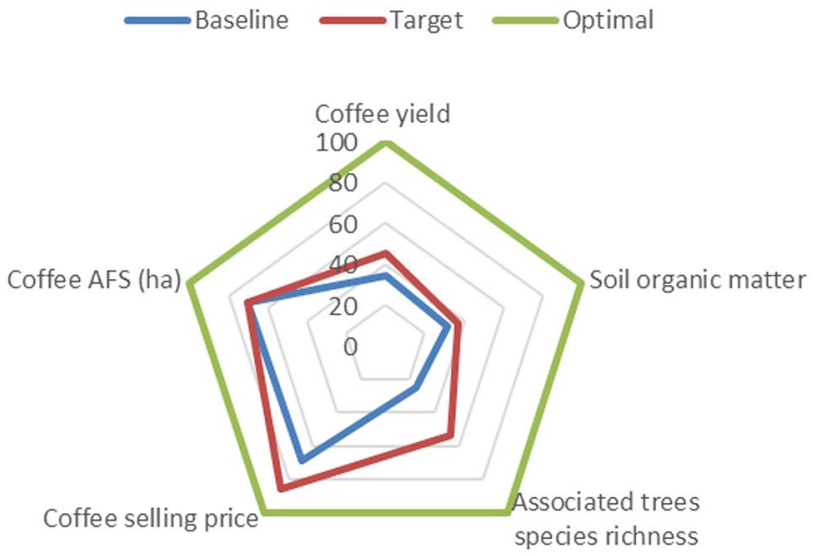

Fig. 6 Current baseline and targets expressed in percentage of the envisioned future landscape for coffee AFS focused on coffee productivity, soil fertility, biodiversity, market and land use. The optimal levels were based on a literature review

the steps needed to reach this future. The envisioned future was based on five pillars of sustainable coffee-based AFS as identified by the participants, namely improved coffee yields, improved soil fertility, increased biodiversity and a 


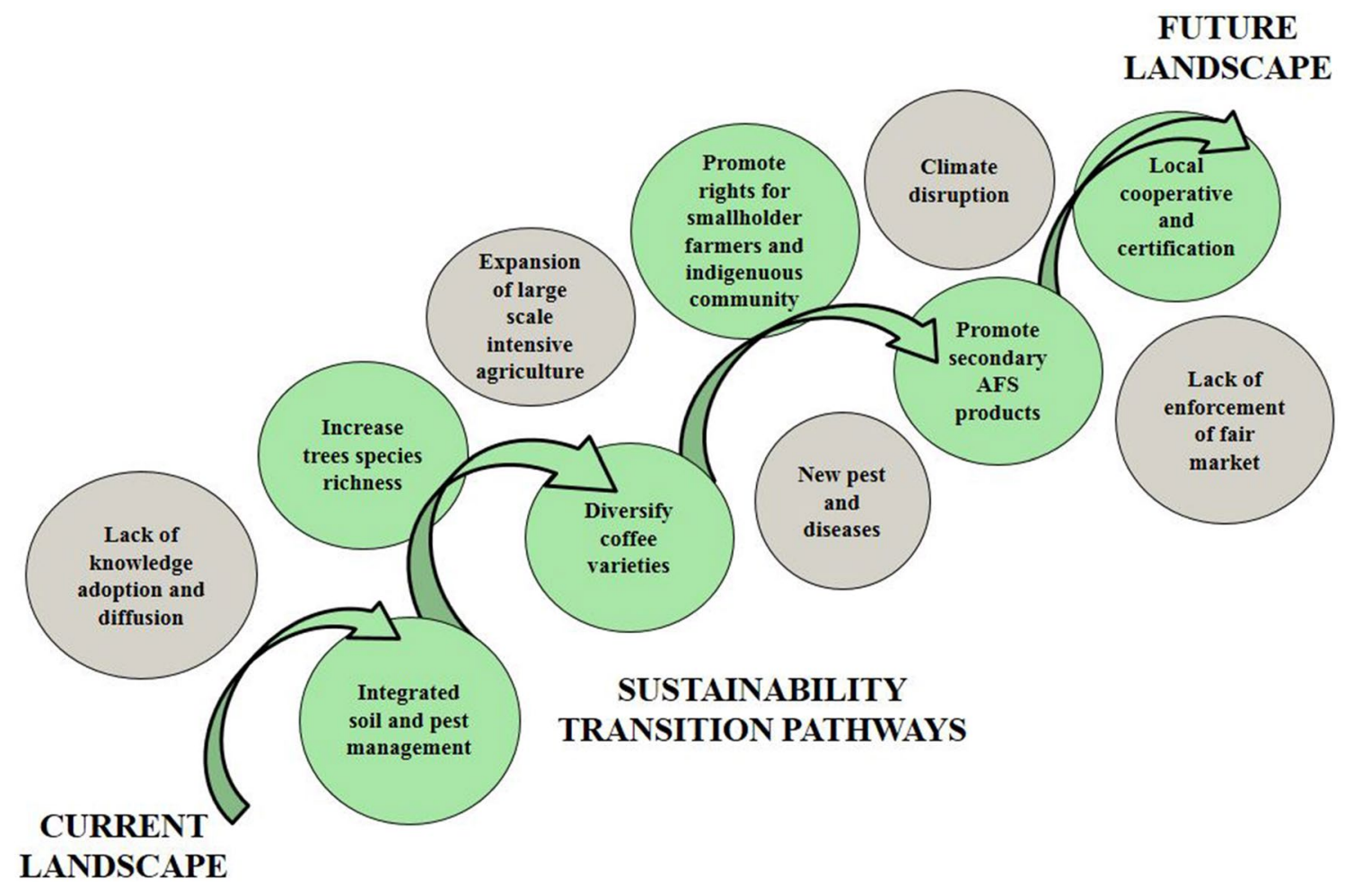

Fig. 7 Policy instruments and community-based solutions pathways for sustainability transition landscape through coffee-based AFS. The green circles indicate the opportunities that help to reach the future desired landscape, while the grey circles are the obstacles

higher coffee price. The participants did not desire to enlarge the farmed area. Collectively the stakeholders who participated in the backcasting workshop developed a course of action for reaching the desired future (Fig. 7).

Farmers in our research used the game as support for learning, sharing knowledge and practices towards opportunities and against the obstacles. The support of serious games as forecasting scenario evaluation tool for agricultural land use planning has been presented in numerous research studies with similar results to ours: educational purpose, knowledge and management practices sharing, conflict mediation and leadership assessment (Garcia et al. 2018; Speelman et al. 2019).

Despite these convincing results obtained during the games sessions we highlighted the limitations of this approach. The limited number of options offered to the participants during the game on the one hand supported the evaluation of future scenarios, but on the other failed on elicit pathways for the desired transition. The game helped them to identify and discuss the difficulties they were facing in real life mainly related to support for production and market access. Farmers envisioned the production of coffee with different products not only for the sake of biodiversity but mainly for the market. In the study area there is a market only for coffee and not for other products (Martínez-Valle et al. 2017). This result is alarming when considering the difficulties that farmers in Tuma-La Dalia have for achieving food security (Bonilla Findji et al. 2017). Bonilla Findji et al. (2017) underlined how these farmers have difficulty to satisfy their food requirements between 3 and 4 months in a year as their main focus is coffee production instead of producing staple foods.

Other research studies that applied serious games also found major difficulties in adapting a unique tool for many contexts and encourage the co-production of these tools with the stakeholders mobilizing arena (Hassenforder et al. 2015) or companion modelling approach (i.e. Falardeau et al. 2019). Through the backcasting we succeeded in exploring the limitation of the four games options, engaging the discussion with the selected leaders on the indicators co-produced with the players during the post-game survey. The pathways for the desired transition included steps for allowing product diversification as developing the market for diverse products and the development of farmers' cooperative and trademark to support this desired future scenario. The scenario co-produced during the backcasting supported the collective evaluation of an optimal scenario but on the other hand only drafted the measures to achieve it. Previous studies have shown that researchers leading perspectives workshops also highlighted this weakness of the backcasting approach, but appreciated how this method is very effective for facilitating the process of co-producing 
scenarios involving local actors bringing local challenges to sustainability transition (Kok et al. 2011; Pedde et al. 2019; Falardeau et al. 2019).

Future research may experiment more with the methods showed in this paper to develop a common framework or protocol to be adapted for specific cases and support not only multi-level stakeholders' participation but also a wider spatial scale which include the local landscape as well as the national and transitional levels. Applying game-changing methods as games and backcasting - taking into consideration the limitations of these methods - can be a constructive and participatory way to support local and international engagement for achieving sustainability.

\section{Conclusions}

The development and implementation of pathways towards sustainable tropical agroforested landscapes require an inclusive participatory approach. In these landscapes, stakeholders collectively have to address a multitude of issues including climate change, pests and diseases and prices. With suitable approaches to facilitate this co-production of sustainable landscape management still largely lacking, we presented a novel method based on the combination of forecasting game sessions and backcasting workshops. We presented a case study in the coffee-based agroforested landscapes of central Nicaragua where our approach allowed local stakeholders to define and explore distinct management strategies towards a sustainability transition in agroforestry management.

Acknowledgements This study was financially supported by the STRADIV project (Grant no. 1504-003) funded by Agropolis Foundation. We are also grateful to the technician Alcide Quintero for his help for the fieldwork and to the UCA cooperative in La Dalia, for their support with regards to workshop organisation. Finally, we would like to thank two anonymous reviewers for their thoughtful comments and efforts towards improving our manuscript.

Open Access This article is licensed under a Creative Commons Attribution 4.0 International License, which permits use, sharing, adaptation, distribution and reproduction in any medium or format, as long as you give appropriate credit to the original author(s) and the source, provide a link to the Creative Commons licence, and indicate if changes were made. The images or other third party material in this article are included in the article's Creative Commons licence, unless indicated otherwise in a credit line to the material. If material is not included in the article's Creative Commons licence and your intended use is not permitted by statutory regulation or exceeds the permitted use, you will need to obtain permission directly from the copyright holder. To view a copy of this licence, visit http://creativecommons.org/licenses/by/4.0/.

\section{References}

Altieri MA (1989) Agroecology: a new research and development paradigm for world agriculture. Agric Ecosyst Environ 27:37-46

Andreotti F, Mao Z, Jagoret P, Speelman EN, Gary C, Saj S (2018) Exploring management strategies to enhance the provision of ecosystem services in complex smallholder agroforestry systems. Ecol Ind 94:257-265. https://doi.org/10.1016/j.ecoli nd.2018.06.048

Andrieu N, Howland F, Alba IA, Le Coq JF, Osorio AM, MartinezBaron D, Chia E (2019) Co-designing climate-smart farming systems with local stakeholders: a methodological framework for achieving large-scale change. Front Sustain Food Syst 3:37

Avelino J, ten Hoopen GM, DeClerck FA (2012) Ecological mechanisms for pest and disease control in coffee and cacao agroecosystems of the Neotropics. In: Rapidel B, DeClerck FAJ, Le Coq J-F, Beer J (eds) Ecosystem services from agriculture and agroforestry. Routledge, Abingdon, pp 125-152

Barnaud C, Van Paassen A, Trébuil G, Promburom T, Bousquet F (2010) Dealing with power games in a companion modelling process: lessons from community water management in Thailand highlands. J Agric Educ Ext 16(1):55-74

Bergez JE, Duru M, Hazard L, Therond O (2014) TATA-BOX: "Territorial Agroecological Transition in Action": a tool-Box for designing and implementing a transition to a territorial agroecological system in agriculture. In: 11th European IFSA symposium, farming systems facing global challenges: capacities and strategies, proceedings, Berlin, Germany, 1-4 April 2014 (pp 1317-1327). International Farming Systems Association (IFSA) Europe

Beveridge L, Whitfield S, Fraval S, van Wijk M, van Etten J, Mercado $\mathrm{L}$ et al (2019) Experiences and drivers of food insecurity in Guatemala's dry corridor: insights from the integration of ethnographic and household survey data. Front Sust Food Syst 3:65

Bonilla-Findji O, Alvarez-Toro P, Martinez-Baron D, Ortega LA, Leguia-Hidalgo E, Aguilar A, Paz L, Suchini JG (2017) Latin America Climate-Smart Villages AR4D sites: 2016 Inventory. Wageningen, The Netherlands: CGIAR Research Program on Climate Change, Agriculture and Food Security (CCAFS). Implementing partners CGIAR Centers Local partners, 2.

Cerda R, Allinne C, Gary C, Tixier P, Harvey CA, Krolczyk L et al (2017) Effects of shade, altitude and management on multiple ecosystem services in coffee agroecosystems. Eur J Agron $82: 308-319$

Cerda Bustillos R, Orozco Aguilar L, Carreño Rocabado G, Ordóñez JC, Amores Contreras FM, Caicedo Albán WJ, Oblitas Gillés de Péliche S, Somarriba Chávez E (2019) Tropical agroforestry and ecosystem services: trade-off analysis for better design strategies. Agroforestry for Sustainable Agriculture

Davies AR (2014) Co-creating sustainable eating futures: technology, ICT and citizen-consumer ambivalence. Futures 62:181-193

Downing JA, McClain M, Twilley R, Melack JM, Elser J, Rabalais NN et al (1999) The impact of accelerating land-use change on the $\mathrm{N}$-cycle of tropical aquatic ecosystems: current conditions and projected changes. Biogeochemistry 46(1-3):109-148

Durand-Bessart C, Tixier P, Quinteros A, Andreotti F, Rapidel B, Tauvel C, Allinne C (2020) Analysis of interactions amongst shade trees, coffee foliar diseases and coffee yield in multistrata agroforestry systems. Crop Protection 133:105137

Duru M, Therond O, Fares MH (2015) Designing agroecological transitions; a review. Agron Sustain Dev 35:1237-1257

Étienne M (ed) (2013) Companion modelling: a participatory approach to support sustainable development. Springer, Berlin

Falardeau M, Raudsepp-Hearne C, Bennett EM (2019) A novel approach for co-producing positive scenarios that explore agency: case study from the Canadian Arctic. Sustain Sci 14(1):205-220 
Fraser J, Fisher E, Arce A (2013) Reframing 'crisis' in fair trade coffee production: trajectories of agrarian change in Nicaragua. J Agrar Change 14:52-73

Gaitán-Cremaschi D, Klerkx L, Duncan J, Trienekens JH, Huenchuleo C, Dogliotti S et al (2019) Characterizing diversity of food systems in view of sustainability transitions. A review. Agro Sustain Dev 39(1): 1

Garcia C, Vende J, Konerira N, Kalla J, Nay MM, Dray A et al (2018) Understanding coffee farmers: using games to explore future coffee agroforestry landscapes in the Western Ghats (India). https:// doi.org/10.31220/osf.io/9374a

García-Barrios LE, Speelman EN, Pimm MS (2008) An educational simulation tool for negotiating sustainable natural resource management strategies among stakeholders with conflicting interests. Ecol Model 210(1-2):115-126

Barrios LEG, Barrios JRG, Morales JC, Smith J (2015) When death approaches: reverting or exploiting emergent inequity in a complex land-use table-board game. Ecol Soc 20(2):154-170

Goodall KE, Bacon CM, Mendez VE (2015) Shade tree diversity, carbon sequestration, and epiphyte presence in coffee agroecosystems: a decade of smallholder management in San Ramón, Nicaragua. Agric Ecosyst Environ 199:200-206

Goodman LA (1961) Snowball sampling. Ann Math Stat 32:148-170

Haggar J, Jerez R, Cuadra L, Alvarado U, Soto G (2012) Environmental and economic costs and benefits from sustainable certification of coffee in Nicaragua. Food Chain 2(1):24-41

Haggar J, Asigbaase M, Bonilla G, Pico J, Quilo A (2015) Tree diversity on sustainably certified and conventional coffee farms in Central America. Biodiver Conser 24(5):1175-1194

Harvey C, Komar O, Chazdon R, Ferguson B, Finegan B, Griffith D, Martínez-Ramos M, Morales H, Nigh R, Soto-Pinto L, Van B, Wishnie M (2008) Integrating agricultural landscapes with biodiversity conservation in the Mesoamerican hotspot. Conserv Biol 22(1):8-15

Harvey CA, Chacón M, Donatti CI, Garen E, Hannah L, Andrade A, Bede L, Brown D, Calle A, Chará J, Clement C, Gray E, Hoang MH, Minang P, Rodríguez AM, Seeberg-Elverfeldt C, Semroc B, Shames S, Smukler S, Somarriba E, Torquebiau E, van Etten J, Wollenberg E (2014) Climate-smart landscapes: opportunities and challenges for integrating adaptation and mitigation in tropical agriculture. Conserv Lett 7:77-90

Hassenforder E, Ferrand N, Pittock J, Daniell KA, Barreteau O (2015) A participatory planning process as an arena for facilitating institutional bricolage: example from the Rwenzori region, Uganda. Soc Nat Resour 28(9):995-1012

Hazard L, Steyaert P, Martin G, Couix N, Navas ML, Duru M et al (2018) Mutual learning between researchers and farmers during implementation of scientific principles for sustainable development: the case of biodiversity-based agriculture. Sustain Sci 13(2):517-530

Hernández Sandoval B, Garcia B, Garrish V, Cherrington E, Picado F, Sempris E (2011) Mapa Centroamericana de cobertura y uso de la tierra, cambios de cobertura y uso de la tierra 1980-1990-20002010. https://doi.org/10.13140/RG.2.2.16349.82409

Herrero-Jáuregui C, Arnaiz-Schmitz C, Herrera L, Smart SM, Montes C, Pineda FD, Schmitz MF (2019) Aligning landscape structure with ecosystem services along an urban-rural gradient. Tradeoffs and transitions towards cultural services. Landsc Ecol 34(7):1525-1545

Hoolohan C, Larkin A, McLachlan C, Falconer R, Soutar I, Suckling J et al (2018) Engaging stakeholders in research to address water-energy-food (WEF) nexus challenges. Sustain Sci 13(5):1415-1426

Imbach P, Beardsley M, Bouroncle C, Medellin C, Läderach P, Hidalgo H, Alfaro E, Van Etten J, Allan R, Hemming D, Stone R, Hannah L, Donatti CI (2017) Climate change, ecosystems and smallholder agriculture in Central America: an introduction to the special issue. Clim Change 141:1-12

Jha S, Bacon CM, Philpott SM, Ernesto Mendez V, Läderach P, Rice RA (2014) Shade coffee: update on a disappearing refuge for biodiversity. Bioscience 64(5):416-428

Kabaya K, Hashimoto S, Fukuyo N, Uetake T, Takeuchi K (2019) Investigating future ecosystem services through participatory scenario building and spatial ecological-economic modelling. Sustain Sci 14(1):77-88

Kishita Y, Hara K, Uwasu M, Umeda Y (2016) Research needs and challenges faced in supporting scenario design in sustainability science: a literature review. Sustain Sci 11(2):331-347

Kok K, van Vliet M, Bärlund I, Dubel A, Sendzimir J (2011) Combining participative backcasting and exploratory scenario development: experiences from the SCENES project. Technol Forecast Soc Change 78(5):835-851

Laderach P, Lundy M, Jarvis A, Ramirez J, Portilla EP, Schepp K, Eitzinger A (2011) Predicted impact of climate change on coffee supply chains. In: Leal Filho W (ed) The economic, social and political elements of climate change. Springer, Berlin, pp 703-723

Lasco RD, Delfino RJP, Espaldon MLO (2014) Agroforestry systems: helping smallholders adapt to climate risks while mitigating climate change. Wiley Interdiscip Rev Clim Change 5(6):825-833

Martínez-Valle A, Czaplicki S, Collado C, Parker L, Bourgoin C, Guerten N, Lan LN, Läderach P (2017) Pragmatic economic valuation of adaptation risk and responses across scales in Nicaragua. Working Paper No. 210. CGIAR Research Program on Climate Change, Agriculture and Food Security (CCAFS), Wageningen, The Netherlands

Mendez VE (2008) Farmers' livelihoods and biodiversity conservation in a coffee landscape of El Salvador. Confronting the coffee crisis: fair trade, sustainable livelihoods and ecosystems in Mexico and Central America. MIT Press, Cambridge, pp 207-236

Meynard J-M, Jeuffroy M-H, Le Bail M, Lefèvre A, Magrini M-B, Michon C (2017) Designing coupled innovations for the sustainability transition of agrifood systems. Agric Syst 157:330-339

Moguel P, Toledo VM (1999) Biodiversity conservation in traditional coffee systems of Mexico. Conserv Biol 13(1):11-21

Montagnini F (ed) (2017) Integrating landscapes: agroforestry for biodiversity conservation and food sovereignty, vol 494. Springer, Berlin

Moreau C, Barnaud C, Mathevet R (2019) Conciliate agriculture with landscape and biodiversity conservation: a role-playing game to explore trade-offs among ecosystem services through social learning. Sustainability 11(2):310

Nelson V, Phillips D (2018) Sector, landscape or rural transformations? Exploring the limits and potential of agricultural sustainability initiatives through a cocoa case study. Bus Strateg Environ 27(2):252-262

Newell P (2019) Climate smart agriculture? Governing the sustainable development goals in Sub-Saharan Africa. Front Sustain Food Syst 3:55

Pedde S, Kok K, Onigkeit J, Brown C, Holman I, Harrison PA (2019) Bridging uncertainty concepts across narratives and simulations in environmental scenarios. Reg Environ Change 19(3):655-666

Philpott SM, Soong O, Lowenstein JH, Pulido AL, Lopez DT, Flynn DF, DeClerck F (2009) Functional richness and ecosystem services: bird predation on arthropods in tropical agroecosystems. Ecol Appl 19(7):1858-1867

Poole N, Donovan J (2014) Building cooperative capacity: the specialty coffee sector in Nicaragua. J Agribus Dev Emerg Econ 4:133-156

Rapidel B, Ripoche A, Allinne C, Metay A, Deheuvels O, Lamanda N, Blazy JM, Valdés-Gómez H, Gary C (2015) Analysis of ecosystem services trade-offs to design agroecosystems with perennial crops. Agron Sustain Dev 35(4):1373-1390 
Saj S, Durot C, Mvondo Sakouma K, Tayo Gamo K, Avana-Tientcheu ML (2017) Contribution of associated trees to long-term species conservation, carbon storage and sustainability: a functional analysis of tree communities in cacao plantations of Central Cameroon. Int J Agric Sustain 15(3):282-302

Sauvadet M, Meersche KVD, Allinne C, Gay F, Filho EDMV, Chauvat M, Becquer T, Tixier P, Harmand J-M (2019) Shade trees have higher impact on soil nutrient availability and food web in organic than conventional coffee agroforestry. Sci Total Environ 649:1065-1074

Sayer J, Sunderland T, Ghazoul J, Pfund JL, Sheil D, Meijaard E et al (2013) Ten principles for a landscape approach to reconciling agriculture, conservation, and other competing land uses. Proc Natl Acad Sci 110(21):8349-8356

Schiller K, Godek W, Klerkx L, Poortvliet PM (2020) Nicaragua's agroecological transition: Transformation or reconfiguration of the agri-food regime?. Agroecol Sustain Food Syst 44(5):611-628

Schroth G, Krauss U, Gasparotto L, Aguilar JD, Vohland K (2000) Pests and diseases in agroforestry systems of the humid tropics. Agrofor Syst 50(3):199-241

Sepúlveda N, Vågen T-G, Winowiecki LA, Chiputwa B, Somarriba E, Lopez Sampson A (2018) Sentinel landscape stocktaking pilot study report Nicaragua-Honduras. CATIE, ICRAF, p 91

Sepúlveda N, Vågen TG, Winowiecki LA, Ordoñez J, Chiputwa B, Makui $P$ et al (2020) Sentinel landscape stocktaking pilot study: report Nicaragua-Honduras. The CGIAR Research Program on Forests, Trees and Agroforestry (FTA)

Somarriba E, Carreño-Rocabado G, Amores F, Caicedo W, Gillés Oblitas, de Pélichy S, Cerda R, Ordóñez JC (2017) Trees on farms for livelihoods, conservation of biodiversity and carbon storage: evidence from Nicaragua on This "invisible" resource. In: Montagnini F (ed) Integrating landscapes: agroforestry for biodiversity conservation and food sovereignty. Springer International Publishing, Cham, pp 369-393

Speelman EN, García-Barrios LE (2010) The RESORTES (Redes Sociales y Ordenamiento Territorial Sustentable). Unpublished boardgame

Speelman EN, García-Barrios LE, Groot JCJ, Tittonell P (2014a) Gaming for smallholder participation in the design of more sustainable agricultural landscapes. Agric Syst 126(2014):62-75

Speelman EN, Groot JC, García-Barrios LE, Kok K, van Keulen H, Tittonell P (2014b) From coping to adaptation to economic and institutional change - trajectories of change in land-use management and social organization in a Biosphere Reserve community, Mexico. Land Use Policy 41:31-44

Speelman EN, van Noordwijk M, Garcia C (2017) Gaming to better manage complex natural resource landscapes. In: Co-investment in ecosystem services: global lessons from payment and incentive schemes. World Agroforestry Centre, pp 1-11

Speelman EN, Rodela R, Doddema M, Ligtenberg A (2019) Serious gaming as a tool to facilitate inclusive business; a review of untapped potential. Curr Opin Environ Sustain 41:31-37

Tejedor G, Segalas J (2018) Action research workshop for transdisciplinary sustainability science. Sustain Sci 13(2):493-502

Tscharntke T, Clough Y, Bhagwat SA, Buchori D, Faust H, Hertel D, Scherber C (2011) Multifunctional shade-tree management in tropical agroforestry landscapes-a review. J Appl Ecol 48(3):619-629

van der Ploeg JD, Barjolle D, Bruil J, Brunori G, Madureira LMC, Dessein J, Drag Z, Fink-Kessler A, Gasselin P, de Molina MG, Gorlach K, Jürgens K, Kinsella J, Kirwan J, Knickel K, Lucas V, Marsden T, Maye D, Migliorini P, Milone P, Noe E, Nowak P, Parrott N, Peeters A, Rossi A, Schermer M, Ventura F, Visser M, Wezel A (2019) The economic potential of agroecology: empirical evidence from Europe. J Rural Stud 71:46-61

van Noordwijk M, Coe R, Sinclair F (2016) Central hypotheses for the third agroforestry paradigm within a common definition. ICRAF working paper

Vergragt PJ, Quist J (2011) Backcasting for sustainability: Introduction to the special issue. Technol Forecast Soc Change 5(78):747-755

Villamor GB, van Noordwijk M (2011) Social role-play games vs individual perceptions of conservation and PES agreements for maintaining rubber agroforests in Jambi (Sumatra), Indonesia. Ecol Soc 16(3):27

Warner K (2007) Agroecology in action: extending alternative agriculture through social networks. MIT, Cambridge

Wilson BR (2013) Breaking the chains: coffee, crisis, and farmworker struggle in Nicaragua. Environ Plan A 45(11):2592-2609

Publisher's Note Springer Nature remains neutral with regard to jurisdictional claims in published maps and institutional affiliations.

\section{Affiliations}

\section{Federico Andreotti ${ }^{1,2,3,4}$ (1) Erika N. Speelman ${ }^{1} \cdot$ Karel Van den Meersche ${ }^{4,8,9} \cdot$ Clementine Allinne $^{4,5,6,7}$}

1 Laboratory of Geo-information Science and Remote Sensing, Wageningen University and Research, 6708 PB Wageningen, The Netherlands

2 CIRAD, UPR GREEN, 34398 Montpellier, France

3 GREEN, Univ. Montpellier, CIRAD, Montpellier, France

4 PCP Agroforestry MesoAmerica: Pôle de Compétences en Partenariat, Montpellier, France

5 CIRAD, UMR System, Turrialba, Costa Rica
6 System, Univ Montpellier, CIRAD, INRA, Montpellier SupAgro, 34000 Montpellier, France

7 CATIE, Turrialba 7170, Costa Rica

8 Eco\&Sols, Univ Montpellier, IRD, INRA, CIRAD, Montpellier SupAgro, 34000 Montpellier, France

9 CIRAD, UMR Eco\&Sols, 34060 Montpellier, France 